https://doi.org/10.18485/iipe_euchanges.2021.ch14

\title{
SLOVENIAN DEMOCRATIC STRUGGLES AFTER THE EU ACCESSION
}

\begin{abstract}
Miro HAČEK ${ }^{1}$
Abstract: In the third wave of democratic changes in the early 1990s, when the Central and Eastern European (CEE) political landscape changed radically, and democratization processes started in the eastern part of the continent, Slovenia was one of the most prominent countries with the best prospects for democratic growth. Slovenia escaped the Yugoslav civil wars, and at the end of the $20^{\text {th }}$ century was already on the path towards stable and consolidated democracy with the most successful economy in the entire CEE area. After gaining independence, Slovenia had a simple and straightforward political goal to join the EU and consolidate its place among the most developed countries within the region. This goal was accomplished in a big enlargement to the EU in May 2004. But has what happened after Slovenia managed to successfully achieve its pair of major political goals? We are searching for answers in this paper when analysing why Slovenian voters are increasingly distrustful not only towards political institutions, why so-called new political faces and instant political parties are very successful and why Slovenian democracy lost the leading place among consolidated democracies in CEE.
\end{abstract}

Keywords: Slovenia; European Union; membership; public distrust; democracy.

\section{INTRODUCTION}

Ever since having declared its independence from former Yugoslavia in 1991, the Republic of Slovenia has expressed its willingness and objective, both in its strategic development documents and at the highest political

\footnotetext{
${ }^{1}$ Full professor of political science at the University of Ljubljana, Slovenia and president of the Central European Political Science Association (CEPSA). E-mail: miro.hacek@fdv.uni-lj.si
} 
levels, to become a full member of the EU (EU). ${ }^{2}$ As the crucial developmental documents ${ }^{3}$ indicate, the optimum long-term development of the Slovenian economy is inextricably tied to Slovenia's full membership in the EU. Thus, soon after the country's independence, membership in the EU became one of Slovenia's key objectives. In June 1996, a treaty on the integration of Slovenia into the EU was enacted, enabling Slovenia to start negotiations on full membership in the EU, along with some other former socialist states from CEE. The treaty enabled political dialogue, increased commercial co-operation, established the grounds for technical and financial support from the EU and also supported the integration of Slovenia into the EU. All parliamentary political parties with a single exception (far right Slovenian National Party), supported the integration and signed a joint treaty on co-operation for this purpose. The National Assembly passed a decree on the priority of discussing European legislation, thereby accelerating the adoption of the Acquis Communautaire. Membership in the EU became the national interest (Fink-Hafner \& Lajh, 2005, p. 55-56). Accession negotiations between Slovenia and the Union were completed during 2002, and in April 2003 the Treaty on Accession of Slovenia to the EU was signed. Hence, on 1 May 2004, Slovenia became part of the European family of nations. In this manner, the Acquis Communautaire became part of Slovenian legislation and European affairs became internal affairs of Slovenia.

The support for EU membership was quite stable during the accession process, resulting in good turnout (60.4 percent) and support (89.6 percent) at the referendum on joining the EU, which was carried out on 23 March 2003 (Haček et al., 2017, p. 150). The referendum was more or less just a formality due to the high level of public support, which did not dissipate over the years but even increased when the accession date approximated (Velič, 2003). Among the ten countries joining the EU in spring 2004, the highest support for the membership was recorded in Lithuania (52 percent of survey respondents saying it was good for their country to become a member of the EU), followed by Malta (50 percent). Slovenia, at 40 percent, was on the lower end, surpassing only Latvia (33 percent) and Estonia (31

\footnotetext{
${ }^{2}$ We will uniformly use the term EU (EU) in this article, acknowledging the term European Communities pre-1993.

${ }^{3}$ See, e.g., Slovenia's Economic Development Strategy, The Strategy of International Economic Relations of Slovenia, Strategy for Improving the Competitiveness of the Slovenian Industry, etc.
} 
percent). However, the citizens of Slovenia (64 percent), Hungary and Lithuania (both 58 percent) most often expressed expectations of certain benefits as a result of their country's membership. In the period from spring 2003 to spring 2004, the trend of support for EU membership in Slovenia reflected the average for the new Member States at the time of the referendum on Slovenia's accession (spring 2003), when support reached its peak (57 percent), followed by a trend of decreasing support. In the period 1999-2002, support in Slovenia was continuously below the average for the new Member States (between five percent and eleven percent). However, the percentage of inhabitants of Slovenia who maintained that EU membership would be detrimental to Slovenia was consistently lower as well, ranging from seven to 17 percent (Eurobarometer 62, 2004, p. 18; see also Haček \& Kukovič, 2014, p. 106).

The goal of this paper is not, however, to analyse and evaluate the processes of the Slovenian accession process to the EU, but to analyse and evaluate the main political, societal and economic developments in far less known and analysed period, i.e., the period after the Slovenian accession to the EU that influenced the democratic development of the country in both positive and negative ways. We are searching for answers to the basic question, which firstly focuses on the three periods, i.e., the EU accession, the right-wing Janša's government and the beginning of the global economic crisis (2004-2009), the global crisis (mis)management and politico-economic consequences (2009-2014), and the recovery period (2014-2020). The analysis is searching for an answer to the questions why Slovenian voters are increasingly distrustful not only towards national politics but also towards the EU per se and EU institutions, why so-called new political faces and instant political parties thrive in Slovenia, and why Slovenian democracy took some damage and lost leading place among consolidated democracies in CEE.

\section{THE EU ACCESSION AND EARLY YEARS OF MEMBERSHIP}

Romano Prodi, President of the European Commission, welcomed the 75 million "new fellow citizens" on 1 May 2004 as he attended celebrations marking the expansion of the EU to ten new members in Nova Gorica. He was joined by Slovenian Prime Minister Anton Rop, who in turn welcomed Europe. Just a month and a half after the entry, Slovenia was faced with the first major EU event, as the first European Parliament elections in Slovenia were held on 13 June 2004. There were 91 candidates (42 females) for the 
seven Slovenian seats in the European Parliament. Candidates were grouped into 13 candidacy-lists among which there were seven parliamentary parties and six non-parliamentary parties or other groups. European parliamentary elections 2004 were marked by the worst turnout to date -45.7 percent. The turnout even decreased in the 'old' member states of the EU (compared to the 1999 elections), but what was the most alarming was the turnout in the new member states. Slovenia and the Czech Republic both had a 28.4 percent turnout, which only outperformed Estonia and Slovakia - in the latter, it was as low as 17 percent. Such a poor turnout was interpreted as the result of the insufficient appraisal of the importance of these elections and the European Parliament's work (Haček et al., 2017, p. 147). But those were not the only reasons, as the poor electoral turnout in Slovenia was also caused by growing dissatisfaction with politics, the general disinterest of the public and its incomprehension. The key factor in electing Slovenian representatives was the candidate's personal charisma and popularity. This was clearly visible by the election of Borut Pahor (SD) through preferential voting, even if he was the last name on the list. Elections to the European parliament were a clear indicator of coming political changes, as four out of the seven elected representatives were on the opposition lists.

Regular parliamentary elections were held on 3 October 2004 and brought substantial political shift as twelve-year long reign of Liberal Democracy ended, forecasted already by the retreat of long-term Prime Minister Janez Drnovšek to the post of President of the Republic in 2002 and the results of the elections to European Parliament a few months before. For the first time, the winner of the elections was the Slovenian Democratic Party (SDS), which received 29.1 percent of the votes and formed a centre-right coalition government under the leadership of new Prime Minister Janez Janša. The new centre-right government had three big challenges ahead (Haček et al., 2017, p. 202-205), all three closely connected with the EU.

The first one was the adoption of the Common Currency. Slovenia introduced the Euro on 1 January 2007 and joined the Eurozone as the first new Member State. The transition from Slovenian Tolar to the Euro mostly ran swiftly and smoothly, causing no major problems as the population had been informed of the new currency in advance, people had a very positive attitude towards the common currency and were expecting mostly positive effects.

The second challenge was entry into the Schengen Area on 22 December 2007, when Slovenia ceased to execute border control of internal land and 
maritime borders with the EU Member States. By entering the Schengen Area, Slovenia abolished border control on its borders with Austria, Italy and Hungary, while intensifying control on the border with Croatia, which became a Schengen external border.

The third challenge seemed like the most demanding one, as Slovenia took over the Presidency of the Council of the EU and led the community uniting 27 Member States and almost half a billion people. Slovenia grasped an exceptional historical opportunity, as this was the first Presidency of a Member State that entered the Union in the 2004 enlargement and the first Council of the EU Presidency of a Slavic state ever. The Presidency of the Council of the EU turned out to be one of the most demanding and complex tasks in terms of contents and a challenge in the organizational and logistical sense at the same time.

The next regular parliamentary elections were held in September 2008 and were again very politically intense, and once again brought a complete political U-turn, as the right-wing ruling coalition suffered defeat and one of the coalition parties (NSi - New Slovenia-Christian People's Party) even failed to reach four percent parliamentary threshold. ${ }^{4}$ The political U-turn has already announced itself beforehand: a) with the win of formally nonpartisan, but in political reality left-wing adored, mayor of national capital Ljubljana, Zoran Janković at local elections in 2006 (Kukovič, 2018a, p. 88); b) the unexpected defeat of coalition-candidate Lojze Peterle, president of the first democratically elected government in the 1990s, at presidential elections in 2007 when the election campaign took an extreme ideological turn; c) the emergence of a new left-wing political party ZARES-New Politics that surfaced from the once major political force Liberal Democracy and became the second power on the left side of the political continuum. The reasons for the defeat of the centre-right government after a relatively successful and stable term in office are multi-layered. In large part, the result of the profound socio-political cleavage in Slovenian society, originating from the early $20^{\text {th }}$ century political cleavages that intensified to shocking civil-war-like proportions during the Second World War and failed to subdue even to this very day. The results of this political cleavage are also constant political, economic and societal conflict between the so-called left-

\footnotetext{
${ }^{4}$ New Slovenia-Christian People's Party is also the only political party in modern Slovenian history to bounce back at the next parliamentary elections (held in December 2011), where they managed to get 4.9 percent of the votes to re-enter the parliament.
} 
wing political forces that are more closely connected and supported by the NGOs and major media outlets, and mostly less influential right-wing political forces, which failed to seize the opportunity presented to them during the democratic transition period after the end of communism to make up for the half-century deficit between the 1940s and 1990s.

\section{THE PAINFUL YEARS OF THE GLOBAL CRISIS AND DEMOCRATIC REGRESSION}

Almost immediately after the new left-wing government took over in November 2008, the impact of the world economic crisis hit Slovenia hard. It was visible to the Slovenian public and the opposition that the government had great difficulties dealing with the crisis. As it appeared, not only with the major economic crisis but also with the major political crisis, followed by the inability of the then Prime Minister Borut Pahor to effectively steer the government away from the crisis. Instead, the government appeared to be a week, indecisive, ineffective, and above all, disunited, contributing to the growing distrust of Slovenians towards politics in general and especially towards political parties.

A few months after the shift of political power, the second European Parliament elections since Slovenian membership to the EU was held on 7 June 2009. Just eight months after losing national parliamentary elections, now the leading opposition party Slovenian Democratic Party (SDS), won the elections conclusively, with three elected Members of the European Parliament (MEP), followed by the ruling party of the time, the Social Democrats (SD) with two MEPs, and with ZARES - New Politics, the Liberal Democratic Party (LSD) and the non-parliamentary New Slovenia-Christian People's Party (NSi), each with one elected MEP.

The period of elections to the European parliament was already influenced heavily by the deteriorating economic conditions that also continued into 2010 and 2011. The government prepared several economic reforms to revitalize the economy and again generate economic growth; the most important reforms were retirees reform (Pensions and Disability Insurance Act) and reform of the labour market (Prevention of Illegal Work and Employment Act). The government failed to present and label the reforms as economically necessary and positive to the general public, and consequently, the reforms were met hard by the unions and political opposition, that demanded several corrigenda in each of the reforms and threatened with the referendums, if the demanded corrigenda would not 
be implemented. As neither side was prepared to bend, a triple referendum was held on 5 June 2011 for the first time in recent Slovenian history. The referendum was initiated by the unions and opposition parties, and greatly contributed to the fall of the government three months later. The most important of the three referendums was the referendum on the Pension and Disability Insurance Act, ${ }^{5}$ containing retirement reform. The government put all their efforts and political weight on winning at least this referendum, only to fail completely, as all three legislative acts were rejected persuasively (70.9 to 75.4 percent of the votes against with 40.5 percent voter turnout). The defeat only added fuel to the ongoing political crisis, and the government consequently failed to get the vote of confidence in the National Assembly in September 2011 (Haček et al., 2017, p. 176).

Pahor was more successful in the bilateral relations with neighbouring Croatia that was in negotiations to enter the EU as the latest member state and the second one from the Western Balkans. He negotiated the Arbitration Agreement with Croatian Prime Minister Kosor over the border dispute that originated in the early 1990s when both countries gained independence but failed to agree on the exact border line on land and especially on the seacoast. The border dispute was always useful fuel for internal political squabbles with numerous, sometimes violent incidents, especially in Piran Bay. The Slovenian government managed to sign an arbitration agreement with Croatia in 2009, which determined that the dispute will be resolved in front of the five-member Arbitration Court, established for this case only. The decision made by the Arbitration Court should have been obligatory for both sides. A referendum on the Arbitration Agreement with Croatia over the border dispute between the countries was called by the $86 \mathrm{MPs}$ and carried out in June 2010. With the relatively low turnout (42 percent), surprisingly 51.5 percent voted for the Agreement and only 48.5 percent against it, effectively opening European doors for Croatia to enter the Union.

Triple referendum defeat resulted in the first precocious parliamentary elections, held on 4 December 2011. We also witnessed at-the-time novice political phenomena, as several new political parties were established in the sixty days prior to elections, and two of them ${ }^{6}$ played a critical role in the

\footnotetext{
${ }^{5}$ The other two being referendums on the Prevention of Illegal Work and the Employment Act and Protection of Documents and Archives and Archival Institutions Act.

${ }^{6}$ The first one is the Civil List of Gregor Virant, founded by Gregor Virant, former minister of public administration in the right-wing government from 2004 to 2008;
} 
elections and coalition-building procedures that followed. Precocious elections were surprisingly won by Positive Slovenia (PS) that manage to overtake long-time favourite Slovenian Democratic Party (SDS), but PS leader Zoran Janković failed to understand that in the proportional system he actually needs a ruling coalition in order to be able to get elected as Prime Minister. PS could not form any kind of coalition, and after several political turns, a new right-centre coalition emerged, led by the Slovenian Democratic Party (SDS) and Prime Minister for the second time, Janez Janša. But the coalition proved to be short-lived, as three coalition partners, namely Citizen's Alliance of Gregor Virant (DLGV), DeSUS and SLS abandoned the ruling coalition in the first months of 2013 following the political impacts of the report issued by the Commission for the Prevention of Corruption (CPC). In the report, Prime Minister Janša and opposition leader Janković were accused of violation of financial disclosure obligations, namely both systematically and repeatedly violated the law by failing to properly report their assets to the CPC, according to the CPC. Janša rejected the calls for resignation and the ruling coalition of two right-wing parties (SDS, NSi) was left to rule with only a minority of votes (30) in the National Assembly.

On 27 February 2012, the majority of MPs in the National Assembly supported the vote of no-confidence to the Prime Minister Janša, and at the same time also elected a new Prime Minister, Alenka Bratušek from Positive Slovenia; her election was supported by the centre-left coalition (52 MPs), comprised of Positive Slovenia (PS), Social Democrats (SD), DLGV and the Democratic Party of Pensioners (DeSUS). There was considerable haste in assembling the new government since the National Assembly appointed the new government only in 22 days. The government had to act quickly in an extremely unstable period, marked by a multitude of political and economic affairs and scandals, resulting in particularly frequent changes of ministers, interpellations, serious economic decline and a serious banking sector crisis. However, the government consequently did not fall because of such instabilities, but because of internal discords. Zoran Janković rather surprisingly resumed leadership of the largest coalition party, Positive Slovenia, in April 2014, after he had to retire from the same position the previous year due to incriminating the Commission for Prevention of Corruption's report. For this reason, tensions emerged within the ruling

second is Positive Slovenia, founded by the Mayor of the national capital city of Ljubljana, Zoran Janković, who was always presenting himself as a non-partisan figure, but was also always very strongly in favor of left-wing political parties. 
coalition, which led to the resignation of Alenka Bratušek as Prime Minister, her retreat from the party and the establishment of her own party (Alliance of Alenka Bratušek). All this led to second consecutive early parliamentary elections, which were the first time held during the summer holidays in independent Slovenia on 13 July 2014 with a visibly negative impact on voter turnout (51.7 percent compared to 65.6 percent in 2011).

Amidst the most serious political crisis up to date in modern Slovenian history and just 49 days prior to another early election to the National Assembly, the third European Parliament elections were held on 25 May 2014. The winner of the election (24.8 percent) was again the largest opposition party, the Slovenian Democratic Party (SDS), which won three MEPs, a joint list of Slovenian People's Party (SLS) and New Slovenia Christian People's Party (NSi) won two MEPs, while centre-left parties of Social Democrats (SD), the Democratic party of pensioners (DeSUS) and "I Believe!" list each got one MEP.

\section{THE ECONOMIC CRISIS RECOVERY}

For the second time in a row, a newly formed political party won early parliamentary elections, this time the Party of Miro Cerar (SMC), which was officially established only 41 days prior to elections. The SMC was concentrated mostly around the personality of Miro Cerar, a professor of constitutional law at the University of Ljubljana and long-time expert legal advisor to the National Assembly. The SMC designed its campaign to advocate for the rule of law, higher ethical standards in politics, sustainable development, social responsibility and human dignity, while the new party extensively used voter dissatisfaction with the existing political climate in the country. The Party of Miro Cerar, which in 2015 was renamed into the Modern Centre Party, won 36 mandates and quite easily established a new governing coalition, consisting of the Modern Centre Party (36 MPs), the Democratic Party of Pensioners (DeSUS; 10 MPs) and Social Democrats (SD; $6 \mathrm{MPs})$. At the time of appointment of the government in the National Assembly in September 2014, the new coalition had a total of $52 \mathrm{MPs}^{7}$ Due

\footnotetext{
${ }^{7}$ In the first two years of the 2014-2018 term, the number of coalition MPs has shifted quite a bit. In March 2017, the Party of Modern Centre (SMC) had 35 MPs, the Slovenian Democratic Party 19 MPs, the Democratic Party of Pensioners (DeSUS) 11 MPs, Social Democrats (SD), United Left and New Slovenia - Christian Democrats each had six MPs, and there were five unaligned MPs (two former
} 
to the extremely high number of acquired mandates, the SMC had superiority also inside the government with nine ministers, and both coalition partners had seven ministers between themselves.

Despite bringing a higher degree of political and economic stability to the country and working in more favourable economic conditions in comparison with previous governments, Slovenia remained mostly static in the period of Cerar's government. The government and public authorities faced general distrust due to the ruling coalition's low effectiveness in dealing with systemic problems of capture by influential lobby groups, a continuing trend from the previous periods, despite the ruling Modern Centre Party (SMC) promises of a "different politics of higher ethical standards." Distrust was also chronic with regard to the judiciary and the fight against corruption because the progress that would, for example, allow the prosecution of important individuals, was insufficient. Financial dependence and political capture continued to hamper civil society and the media. Due to internal divisions and a lack of political will, the centre-left coalition was ineffective in tackling the country's major problems, such as the inefficient public healthcare sector and the irresponsible management of the state assets (Lovec, 2018, p. 2-3).

In the term of Cerar's government, the recovery from the economic recession of 2008-2014 continued. The country's robust economic growth, reaching about five percent in 2017 and 2018, helped reduce the fiscal deficit and resulted in a strong decline in unemployment. At the same time, however, the favourable short-term economic situation reduced the pressure on Cerar's government to move on with policy reforms. Although Slovenia features the largest long-term sustainability gap of all EU members, the announced comprehensive health care reform was left to the next government. As for pensions, the Cerar's government eventually agreed with social partners upon the broad outline of pension reform to be adopted in 2020 but refrained from taking any controversial decisions. The tax reform eventually adopted in summer 2016 has been more modest than initially announced, and minor changes announced by the minister of finance for 2017 were only partially implemented. The promised privatisation of Telekom Slovenia, the largest communication company in the country, fell

members of the SMC, two former members of the Alliance of Alenka Bratušek and one former member of the SDS). The Alliance of Alenka Bratušek became the first parliamentary party in modern Slovenian history to lose all (four) MPs to other political groups. 
victim to political opposition from within and outside the governing coalition. The same happened with the promised privatisation of NLB, the largest Slovenian bank (Haček et al., 2019).

In March 2018, Prime Minister Cerar surprisingly resigned pointing to increased criticism from public-sector unions and the strong opposition to the government's high-profile project of a second railroad track to the port of Koper. In yet another early parliamentary election in June 2018, Cerar's Modern Centre Party (SMC) and most other traditional centre-left parties lost votes. However, the rise of a new centre-left party, the Party of Marjan Šarec (Lista Marjana Šarca; LMŠ), a comedian turned mayor who came second in the presidential elections in 2017, allowed the centre-left parties to refuse to even discuss the possibility of forming the ruling coalition with the winner of the elections, the centre-right Slovenian Democratic Party (SDS) of Janez Janša which got twice as many votes as its nearest rival. In September 2018, the five centre-left parties succeeded in forming a minority government tolerated by the far-leftist Levica party, making Marjan Šarec the new Prime Minister (Haček et al., 2019).

The quality of democracy continued to suffer from widespread corruption. While the Cerar's government implemented the AntiCorruption Action Plan adopted in January 2015, and the Commission for the Prevention of Corruption managed to upgrade its supervisor web platform and launch its successor ERAR in July 2016, doubts about the political elite's commitment to fight corruption were raised by two developments in particular. The first involved the non-transparent management of a government project in which a second railway track is to be constructed between Divača and the port of Koper. The second involved investments by Magna Steyr, a Canadian-Austrian company that received large subsidies and unconditional support from the government for a plan to build a new car paint shop close to Maribor but failed to manage things transparently and deliver on its promise of bringing several thousand new jobs to the region. The differences in opinions between the government and civil society organisations on the financial construction of the second railway track project resulted in a referendum being called in September 2017 and repeated because of transparency irregularities on the government's side in May 2018. Nonetheless, the project was not halted as turnout levels for both referendums were too low to render the vote binding, despite the fact that votes opposing the government's plan slightly outnumbered votes in support of the plan in May 2018 (Haček et al., 2019). The dormant conflict between the government and local communities over constitutionally 
guaranteed autonomy of the latter intensified under the Cerar's government (Kukovič, 2018b, p. 185).

During the term of Cerar's government, the first time since the fall of the Berlin wall and democratisation of CEE, Slovenia lost its leading place in the Freedom House's measurement "Democracy Index". This actually happened in 2016 when the Slovenian score dropped substantially for the first time since the early 2000s and Slovenia was overtaken by improving Estonia. The trend, that was not only the result of the failure of Cerar's government, but also of previous governments, also continued in 2017 and 2018, when Slovenian score regressed, and Slovenia was caught up by yet another Baltic country, this time Latvia. The areas where Slovenia especially struggled compared to other most successful countries of democratic consolidation are mainly independent media and judicial framework, which is also consistent with the analysis above.

But by far, the most important event in Slovenian foreign relations in the period of Cerar's government was the Permanent Court of Arbitration's ruling on the border dispute with Croatia. However, the Croatian delegation refused to respect the Court's findings, citing revelations that in 2015 the Slovenian delegation to the Court had inappropriately received confidential information from a judge sitting on the panel. The publication of the Court's decision in June triggered another set of tensions between the two countries, which included blockades and hostile rhetoric by some political actors in Slovenia. The final decision came against the backdrop of disputes related to the delays created by the strict implementation of the Schengen border controls, which Croatia interpreted as Slovenian pressure over the arbitration issue. Slovenia declared that it would block Croatia's accession to the OECD for its supposed lack of respect for international law and sue Croatia in the Court of Justice to the EU over the breach of European law (Lovec, 2018, p. 3, 5). Slovenia submitted a letter of complaint against neighbouring Croatia to the European Commission on 16 March 2018 after Croatia refused to implement an arbitration decision on their border dispute in the Adriatic Sea. The letter submitted by Slovenia contained over a hundred pages of alleged violations of European law that Slovenia says stem from Croatia's refusal to abide by the arbitration court's ruling. According to the procedure, before an EU member state initiates a court proceeding against another member, it must first refer the matter to the Commission. But to the Slovenian disappointment, the Juncker Commission did not support the Slovenian position and decided to remain neutral. The Commission's decision disappointed many in Slovenia and fuelled anti-EU 
sentiment. The decision was widely interpreted as politically motivated, favouring the right-wing coalition that is ruling Croatia and disregarding the rule of law as one of the EU cornerstones at the same time.

The fourth and latest elections to the European Parliament were held on 26 May 2019. Voter turnout was slightly higher than in 2009 and 2014 (28.9 percent), with lower turnouts than in Slovenia recorded only in Slovakia and in the Czech Republic. The winner of the election was once again the largest opposition party Slovenian Democratic Party (SDS) that had a joint list with Slovenian People's Party (26,3 percent), which won three MEPs. Social Democrats (SD) received two MEPs, the leading ruling coalition Party of Marjan Šarec also received two MEPs, while New Slovenia - Christian People's Party (NSi) received one MEPs. ${ }^{8}$ A low turnout at the European elections in Slovenia, which characterize all four elections in the past fifteen years, is primarily due to disillusionment with politics in general, the lack of interest among voters and also lack of understanding about the EU among the electorate. A key factor in the selection of candidates for MEPs among Slovenian voters is the individual's charisma and popularity, which can be seen with the election of all eight candidates through preferential voting in the 2019 elections.

TABLE 1: SATISFACTION WITH THE DEMOCRACY (IN PERCENT)

\begin{tabular}{|c|c|c|c|}
\hline Year & SATISFIED & UNSATISFIED & NO REPONSE \\
\hline $\mathbf{1 9 9 8}$ & 31 & 58 & 11 \\
\hline $\mathbf{1 9 9 9}$ & 39 & 49 & 12 \\
\hline $\mathbf{2 0 0 0}$ & 40 & 48 & 12 \\
\hline $\mathbf{2 0 0 1}$ & 42 & 46 & 12 \\
\hline $\mathbf{2 0 0 2}$ & 44 & 46 & 10 \\
\hline $\mathbf{2 0 0 3}$ & 38 & 55 & 7 \\
\hline $\mathbf{2 0 0 4}$ & 41 & 51 & 8 \\
\hline $\mathbf{2 0 0 5}$ & 34 & 59 & 7 \\
\hline $\mathbf{2 0 0 6}$ & 39 & 51 & 11 \\
\hline
\end{tabular}

${ }^{8}$ Source: National Electoral Commission, available at https:/ / volitve.gov.si/ep2019 /\#/rezultati (28 November 2020). 


\begin{tabular}{|c|c|c|c|}
\hline Year & SATISFIED & UNSATISFIED & NO REPONSE \\
\hline $\mathbf{2 0 0 7}$ & 36 & 58 & 6 \\
\hline $\mathbf{2 0 0 8}$ & 39 & 55 & 6 \\
\hline $\mathbf{2 0 0 9}$ & 32 & 62 & 6 \\
\hline $\mathbf{2 0 1 0}$ & 11 & 86 & 3 \\
\hline $\mathbf{2 0 1 1}$ & 12 & 84 & 4 \\
\hline $\mathbf{2 0 1 2}$ & 12 & 85 & 3 \\
\hline $\mathbf{2 0 1 3}$ & 8 & 87 & 5 \\
\hline $\mathbf{2 0 1 4}$ & 8 & 87 & 5 \\
\hline
\end{tabular}

Source: Arhiv družboslovnih podatkov (2014). Data from the last conducted survey in each calendar year is shown. After 2014 the survey was discontinued. The question was: »Are you generally satisfied or unsatisfied with the development of democracy in Slovenia?«

Globally, public opinion polls show that new democratic systems are faced with a relatively high degree of dissatisfaction with democracy and therefore also with democratic institutions. Additionally, we also see clearly that satisfaction with democracy is a highly unstable phenomenon. Slovenia does not differ much from this general framework. Rather the opposite, since on average more than half of the citizens are constantly dissatisfied with the democratic regime after 2008. In Table 1, we can see that the level of discontent substantially through the years, but especially after 2008 due to the growing impact of the global economic crisis and a sense that the politics is being ineffective in dealing with the crisis. In 2013 and 2014, the level of dissatisfaction with democracy was the highest ever, namely 87 percent. The question is, how high can frustration tolerance actually be and how much can the "fragile" post-socialist democratic political system withstands, before the high levels of dissatisfaction transfer into the denial of the legitimacy of the democratic political system and its key institutions. ${ }^{9}$

${ }_{9}^{9}$ The latest research asking about satisfaction with democracy was conducted in 2020, and 9 percent of respondents were very satisfied with how Slovenian democracy performs, while an additional 23 percent were satisfied (Slovensko javno mnenje 2020). 
To conclude our analysis of the economic recovery period 2014-2020, we should devote some attention also to the coronavirus pandemic crisis of 2020, which effectively ended any economic recovery and growth not only in Slovenia but also globally. In Slovenia, the pandemic coincided with the new government formed in March 2020, just a day after the epidemic was declared. Of course, the new government would not be possible if Prime Minister Šarec did not unexpectedly resign in late-January 2020 because of political scandals, resignations of key ministers, own inabilities to deal with deepening multi-policy crisis and continuous coalition squabbles. A new centre-right government was formed, led yet again by Janez Janša, winner of 2018 parliamentary elections. The new government was not only greeted by the major global health and economic crisis, but also by protests from far-left activists that started even before the government was formed and the state of constant political conflict, fuelled continuously by total distrust of opposition parties, publicly financed NGOs and major media outlets under influence of opposition parties. The government's response towards the coronavirus crisis was especially positive in the first coronavirus wave in spring and summer 2020, which is also reflected from the Eurobarometer 94 survey, where 64 percent of respondents in Slovenia expressed their satisfaction with the government's response to the coronavirus crisis. ${ }^{10}$

\section{CONCLUSION}

At the beginning of this paper, we posed some seemingly simple and straightforward questions that should reveal political development after Slovenia managed to successfully enter the EU. As our extensive analysis clearly shows Slovenia walked a rocky and steep political and economic path during the last 15 years that was not only leading upwards but in some periods also downwards in the dark alleys of democratic regression.

To understand the character of contemporary Slovenian democracy, it is necessary to look back into recent political history. Two key factors, which as a political constancy have determined this development and also largely marked Slovenian political culture, can be identified. The first is ideological exclusivism as an expression of great differences in ideas, while the second one is collectivistic corporatism which, with its tendency to unity, not only

${ }^{10}$ Source: Eurobarometer 94, available at https:/ /ec.europa.eu/commfrontoffice/ publicopinion/index.cfm/ResultDoc/download/DocumentKy/90882 (3 January 2021). 
expressed resistance to political conflicts but also resistance to differences and competition because that could hurt social harmony. Here originates the strong tendency to overcome the divisions in the political space through the creation of grand coalitions, which was the characteristic of the first decade of Slovenian independence. This practice changed after entering the EU in 2004 into a more competitive and conflict mode of policy, which is constituted by a distinction between authority and opposition. Accordingly, the different ways of narrowing the possibilities to express and confront opposite opinions and positions do not benefit the development of parliamentary democracy. But they partly match the prevailing tendencies to narrow the possibilities of direct democracy and spread the influence of governing political parties on non-governmental stakeholders, such as media and NGOs. Also, the reanimation of populist rituals and ideology which co-exist with decreasing sentiments towards the EU and its institutions should not be overlooked, with both tendencies holding back the development of the liberal-democratic characteristics of Slovenian democracy.

Experience Slovenia has had in its construction of a democratic political system since entering into the EU has been subject to varying assessments. The most negative assessments of the Slovenian political system are related to the persistence of authoritarian behaviour patterns and manipulation with democratic institutions that have found their way into the structures of political parties, to the partocracy resulting from this and the bureaucratic sprawl (Haček et al., 2017). Until the mid-2010s, different surveys placed Slovenia among "consolidated democracies" usually with the highest total marks among the CEE countries. However, in 2015 this changed and Slovenia began to regress. The problems of the Slovenian political system, that were further exposed with the inability of the ruling political class to effectively battle the economic and political crisis in the period from 2008 to 2014, are related to various forms of nepotism, clientelism and corruption, the implementation of the rule of law and the insufficiently developed democratic culture and with it, the culture of public and tolerant dialogue. Democracy cannot be effective unless it is underpinned by the rule of law and a well-functioning judicial system, and those are the areas that have become most problematic after the political and economic crisis ended in 2014. As the EU and its institutions are often the ones bringing attention to the issues mentioned and the ones demanding the construction and implementation of reform programs, and as Slovenian politics has grown into a populist partocracy without any sense of democratic accountability towards the electorate since the EU accession, one cannot wonder that the $\mathrm{EU}$ is no longer seen as political and societal fairy-tale honey-land that will 
solve every possible problem in a heartbeat. On the contrary, it is very evident and clear even to an average Slovenian voter that Slovenia today has very little influence in the EU, mostly because of its own miscalculations, politicization of merit bureaucracy and lack of consistent foreign policy.

\section{REFERENCES}

Arhiv družboslovnih podatkov. (2014). Politbarometer, retrieved from https://www.adp.fdv.uni-lj.si/opisi/serija/PB/. Accessed 18 November 2020.

Eurobarometer 62. (2004). Public Opinion in the EU, retrieved from http://ec.europa.eu/public_opinion/archives/eb/eb62/eb62_sl_nat.p df. Accessed 15 November 2020.

Fink-Hafner, D. \& Lajh, D. (2005). Proces evropeizacije in prilagajanje politicnih ustanov na nacionalni ravni (The processes of Europeanization and the adaptation of political institutions on the national level). Ljubljana, Faculty of Social Sciences.

Haček, M., Kukovič, S. \& Brezovšek, M. (2017). Slovenian Politics and the State. Lanham, Boulder, New York and London, Lexington Books.

Haček, M., Pickel, S. \& Bönker, F. (2019). Slovenia Report: Sustainable Governance Indicators 2019. Gutersloh, Bertelsmann Stiftung.

Kukovič, S. (2018a). Coping with demographic challenges: case of Slovenian local communities. Journal of comparative politics, 11(2), pp. 83-100.

Kukovič, S. (2018b). Unique type of Slovenian local leaders: where executive mayors have Mediterranean strength. Studia politica: Romanian political science review, 18(2), pp. 173-192.

Kukovič, S. \& Haček, M. (2016). Attitudes of Slovenian citizens towards the EU since the accession. In Turska-Kawa, A. \& Haček, M. (Eds.), Democratisation processes in Poland and Slovenia: Comparative study (pp. 131-142). Maribor, Lex Localis Publishing House.

Lovec, M. (2018). Nations in Transit: Slovenia, retrieved from https://freedomhouse.org/sites/default/files/NiT2018_Slovenia.pdf. Accessed 29 November 2020.

Slovensko javno mnenje (2020). Ogledalo javnega mnenja - življenje in stališča v času epidemije Covid19. Ljubljana, Center za raziskovanje javnega mnenja in množičnih komunikacij. Retrieved from 
https://www.cjm.si/wp-content/ uploads/2020/07/SUM-SJM20_1_neutezen-853_v4_zadnji-1.pdf. Accessed 3 January 2021.

Velič, M. (2003). Institut referenduma in dosedanja praksa v Republiki Sloveniji, diplomsko delo (The institute of referendum and previous praxis in Slovenia, diploma work). Ljubljana, Faculty of Social Sciences. 